Volume 4 Number 2 August 2018 page 84-90

p-ISSN:2460-1497 and e-ISSN: 2477-3840

DOI: http://dx.doi.org/10.26858/est.v4i2.4351

\title{
Study of Learning Attitudes and Vocabulary Mastery of Short Story Writing Skills
}

\author{
Rina Ari Rohmah ${ }^{1}$, Ratri Isharyadi ${ }^{2}$ \\ ${ }^{1}$ Program Studi Pendidikan IPS, Universitas Pasir Pengaraian \\ Email:rinaarirohmah@gmail.com \\ ${ }^{2}$ Program Studi Pendidikan Matematika, Universitas Pasir Pengaraian \\ Email:arya_math@ymail.com
}

(Received: November-2017; Reviewed: January-2018; Accepted: April-2018; Published: August-2018) access under license CC BY-NC-4.0 (https://creativecommons.org/licenses/by-nc/4.0/).

\begin{abstract}
This research aims to explain how great the contribution of learning attitude and vocabulary mastery towards the short story writing skills ofjunior high school students in Rokan Hulu. This research uses a quantitative approach with a descriptive method and using correlational and regression design. Stratified random sampling technique was done to select the sampel based on high, medium, and low ranking results based on national examination of the SMP2015/2016 of Rokan Hulu. The data of this research is learning attitude scale, mastery of vocabulary score, and short writing skills score.Data were analyzed using a double linear regression test, $t$-test, $F$-test, and determinant coefficient formula to determine the contribution of independent variables on the dependent variable, either single or simultaneous. Results of this study that learning attitude and vocabulary mastery either single or simultaneous contribute significantly towards the short story writing skills. Contribution of learning attitudes and vocabulary mastery simultaneously, partial contribution of learning attitudes and vocabulary mastery to the short story writing skills in a row is $36.3 \%, 27.9 \%$ and $31.4 \%$.
\end{abstract}

Keywords: Contribution; Learning attitude; Vocabulary mastery; writing skills.

\section{INTRODUCTION}

Writing skills is one of the language skills that have a crucial role in the intellectual development of students. This writing skill cannot be separate from teaching and learning activities at school. Through writing activities, students become active in learning and can stimulate students' skills in pouring ideas that are both scientific and imaginative.

Concerning writing skills, Judge (2007) explains that writing as an act of delivering a message (communication) by using written language as a tool or media. Writing skills require students to be able to express their ideas and thoughts in a logical and systematic frame of mind. Writing skills is a skill that requires a lot of practice and practice on a regular basis. To achieve optimal results, the writing can be done by casting the idea clearly. The clarity of this idea depends on the clarity of thought, sentence selection, spelling use, punctuation, and paragraph arrangement. Therefore, to master writing skills requires experience, time, and intensive training.

One of the writing skills that must be mastered by junior high school students is the skill of writing short stories. The skills of writing short stories are contained in the 2013 curriculum, which is listed in Core 4 Competencies (KI 4) to try, process, and present in a concrete realm (using, parsing, assembling, modifying, and making) in accordance with what is learned in school and other similar sources in the perspective / theoretical and basic competence (KD) 4.2 that compile the text of 
observation, descriptive, exposition, explanation, and short story according to the character of the text which will be made either orally or in writing.

Based on the results of preliminary observations and formal interviews with one of the Indonesian language teachers at SMPN 5 Rambah Samo, information was obtained that the short story writing skills were considered by students as difficult skills. Students are still less able to develop the content of short stories and less able in terms of language. In terms of content, students are still difficult in opening short stories, developing the flow, and close the short story. In terms of language, many students experience errors EyD and the use of inappropriate vocabulary.

Associated with attitude, Ahmadi (2007: 154) explains that a person's attitude or actions affect the results of his work. Thus, a change in student learning attitudes toward a particular subject can affect the learning outcomes achieved. The student's attitude to learning influenced by feelings of pleasure or displeasure with the teacher's performance, lessons, or the environment.

Referring to the results of research Zulhafizh et al. (2013) that the learning attitudes contributed $6.8 \%$ of learning outcomes Indonesian language. That is, the results of learning Bahasa improved by increasing the level of learning attitude. Associated with writing short stories, writing short stories is one of the effects of learning Bahasa. So, the learning attitude brings influence to the results of writing short stories. This is in line with the results of Paker and Erarslan (2015: 1) research that students' attitudes toward writing skills have a positive effect on their ability to write.

Furthermore, Musgrove (1998: 8) proves that the history of one's attitude will affect one's ability in writing so that there is a close relationship between learning attitude and writing. Besides, Petrict (2002) reveals that attitudes are an integral part of building the writing skills, attitudes formed as a result of writing experiences that impact on future writing behavior.

In addition to learning attitudes, other factors that affect the skills of short story writing is the mastery of vocabulary. Referring to Riyanti's (2013) opinion, vocabulary mastery is closely related to writing skills. If in the idea of suggesting, both orally and in writing, students are not able to use the right words, then the student does not recognize the meaning of certain words. This mistake or misunderstanding will make it difficult for students to understand what it reads, or what to use when speaking and writing. Also, Juriah (2015) says that if students have a lot of vocabulary well, they can learn elements and language skills quickly. So, one of those language skills is writing.

Furthermore, the results of research conducted by Febrina, et al. (2014) that there is a definite relationship between vocabulary mastery with the ability to write short stories. The results showed that the ability to write short stories influenced by vocabulary mastery of $27.40 \%$ and the rest influenced by other factors. It shows that vocabulary mastery has an essential role in supporting the skills of students in writing short stories.

Based on the above description, shows that the attitude of learning and mastery of vocabulary can make a positive contribution to the skills of writing short stories. Therefore, this research is essential to reveal how much contribution of learning attitude and vocabulary mastery to the skill of writing the short story of junior high school students in Rokan Hulu District.

\section{METHOD}

This research is correlational research. The correlational method is used to explain the relationship between the three variables studied. Based on the relationship, it will be analyzed further to find the contribution of each independent variable (X1 and $\mathrm{X} 2$ ) to the dependent variable $(\mathrm{Y})$.

The population of this study is all students of class IX SMP in Rokan Hulu consisting of 129 junior high schools with 7167 students. Sampling using strata technique. Researchers studied four schools with high, medium, and low criteria that took strata based on UN rank 2015/2016, so obtained SMPN 5 Rambah Samo school with 22 students, SMPN 3 Ujung Batu with 34 students, SMPN 3 Rambah with 23 students, and SMPN 2 Rambah Hilir with 23 students.

This study consists of three variables, namely two independent variables (independent) and one dependent variable (dependent). The independent variables are learning attitudes (X1) and vocabulary mastery (X2), while the dependent variable is the short story writing skill (Y). The data of this research are as follows: (1) data for learning attitude variable (X1) is the score of the result of filling of learning attitude 
scale; variable vocabulary mastery (X2) is the score of vocabulary test results. Furthermore, the variable data of short story writing skill $(\mathrm{Y})$ is the score of skill writing test result of the short story. Then, the data converted into value form.

The instrument used in this study consists of three, namely the scale of attitudes, objective tests, and performance tests. Attitude scale is used to know the student's learning attitude, the scale of attitudes given in the form of a questionnaire covering cognitive, affective, and conative indicators. The cognitive sub-indicator consists of knowledge, understanding, application, and synthesis; affective subindicator consists of acceptance and responsiveness; sib indicative of conative consist of tendency and will.

Learning attitude scale for this trial is 35 items arranged according to Likert scale pattern with alternative answer Strongly Agree (SS), Agree (S), Less Agree (KS), Disagree (TS), and Strongly Disagree (STS). Meanwhile, objective tests are used to determine vocabulary mastery. About objective tests amounted to 40 questions with indicators of the meaning of words and relations of meaning. Meanwhile, the performance test is used to know the result of short story writing skill, where students are asked to write the short story with the theme of friendship. Indicators of short story writing skills consist of: the title, the ability to open a short story, the ability to develop the flow, giving character to the character, the ability to close the story, and the language. As for the steps in developing the research instrument, that is: (1) Assess the theories relating to the three research variables, (2) Determine the indicators based on the theoretical framework used, (3) Define the grid of the three research variables, (4) Prepare the points of the scale of learning attitude attitudes and vocabulary test and make rubric assessment of short story writing skills, (5) Do the preliminary test to determine the validity and reliability. Based on the result of the preliminary test, 35 items learning attitudes statement are valid and reliable with the reliability coefficient of 0.978 . Meanwhile, vocabulary test there are 40 items valid and reliable with the reliability coefficient of 0.897 .

The steps of data collection are as follows: (1) the scale of attitude is given to the students; (2) the student fills each statement in the attitude scale sheet by putting a check mark; (3) students are given objective tests to measure vocabulary mastery; (4) students fill in answer sheets by putting a cross $(\mathrm{X})$ on the answer option that is considered the most correct; (5) students are given performance tests to measure short story writing skills; (6) students perform writing performance tests; and (7) all answer sheets that have been collected are checked according to predetermined aspects and criteria.

Data analysis techniques used to test the research hypothesis that the contribution of learning attitudes and vocabulary mastery of students' short story writing skills used multiple linear regression analysis with the following formula:

$$
Y=a+b_{1} X_{1}+b_{2} X_{2}
$$

which previously performed prerequisite analysis test consisting of normality test, linearity test, multicollinearity test, and heteroscedasticity test.

Based on the normality test of all the variables, it shows that both the learning attitudes data, the vocabulary used and the skill of writing a short story have normal distributed.

Tabel 3.1 Normality test result

One- Sample Kolmogorov-Smirnov Test

\begin{tabular}{llrrr}
\hline & & SIKAP & KOSAKATA & CERPEN \\
\hline $\mathrm{N}$ & & 108 & 108 & 108 \\
Normal & Mean & .5070 & 59.6991 & 70.8889 \\
Parameters ${ }^{\mathrm{a}, \mathrm{b}}$ & Std. Deviation & .17083 & 1537201 & 8.80456 \\
Most Extreme & Absolute & .070 & .083 & .081 \\
Differences & Positive & .059 & .057 & .077 \\
& $\quad$ Negative & -.070 & -.083 & -.081 \\
Test Statistic & .070 & .083 & .081 \\
Asymp. Sig. (2-tailed) & $.200^{\mathrm{c}, \mathrm{d}}$ & $.064^{\mathrm{c}}$ & $.077^{\mathrm{c}}$ \\
a. Test distribution is Normal. & & & \\
b. Calculated from data. & & & \\
c. Lilliefors Significance Correction. & & & \\
\hline d. This is a lower bound of the true significance. \\
\hline \multicolumn{4}{l}{}
\end{tabular}


From the table above, with the criteria of testing when the value of significance is more than the level of significance (0.05), then the data have normal distributed. The values of the significance of learning attitudes, vocabulary mastery, and short story writing skills are 0.200 ; 0.064 and 0.077 , indicating that the three data are more than 0.05 and have normal distributed. Linearity test results can be seen in the following table.

Table 3.2 Linearity test results in short story writing skills with learning attitudes.

\begin{tabular}{cllrrrrr}
\multicolumn{7}{c}{ Anova Table } \\
\hline & & $\begin{array}{l}\text { Sum of } \\
\text { Squares }\end{array}$ & \multicolumn{1}{c}{ df } & Mean Square & \multicolumn{1}{c}{ F } & \multicolumn{1}{c}{ Sig. } \\
\hline CERPEN * & Between Groups & (Combined) & 4764.238 & 44 & 108.278 & 1.932 & .008 \\
SIKAP & & & & & & & \\
& & Linearity & 2314.673 & 1 & 2314.673 & 41.305 & .000 \\
& Deviation from & 2449.565 & 43 & 56.967 & 1.017 & .470 \\
& Linearity & 3530.429 & 63 & 56.039 & & \\
\hline & & 8294.667 & 107 & & & \\
& Within Groups & & & & & &
\end{tabular}

Table 3.3 Linearity test results short story writing skills with vocabulary mastery.

\begin{tabular}{|c|c|c|c|c|c|c|c|}
\hline \multicolumn{8}{|c|}{ Anova Table } \\
\hline & & & \multirow{2}{*}{$\begin{array}{l}\text { Sum of } \\
\text { Squares }\end{array}$} & & & & \\
\hline & & & & df & Mean Square & $\mathrm{F}$ & Sig. \\
\hline \multirow{5}{*}{$\begin{array}{l}\text { CERPEN * } \\
\text { KOSAKATA }\end{array}$} & Between Groups & (Combined) & 4083.628 & 23 & 177.549 & 3.542 & .000 \\
\hline & & Linearity & 2607.041 & 1 & 2607.041 & 52.004 & .000 \\
\hline & & $\begin{array}{l}\text { Deviation from } \\
\text { Linearity }\end{array}$ & 1476.586 & 22 & 56.967 & 1.339 & .172 \\
\hline & Within Groups & & 4211.039 & 84 & 56.039 & & \\
\hline & Total & & 8294.667 & 107 & & & \\
\hline
\end{tabular}

The linearity test criteria are when the deviation from linearity value is more than the significance level (0.05) then the two data have a linear and significant relationship. According to Table 2, the deviation from linearity between short story writing skills and learning attitudes is 0.470 , while between short story writing skills and vocabulary mastery in table 3 is 0.172 . Both values are more than 0.05 significance level, so either between short story writing skills and learning attitudes as well as between short story writing skills and mastery. Vocabulary equally has a linear and significant relationship. The next prerequisite test used is multicollinearity test.

Table 3.4 Multicolinearity test result of learning attitudes and vocabulary mastery

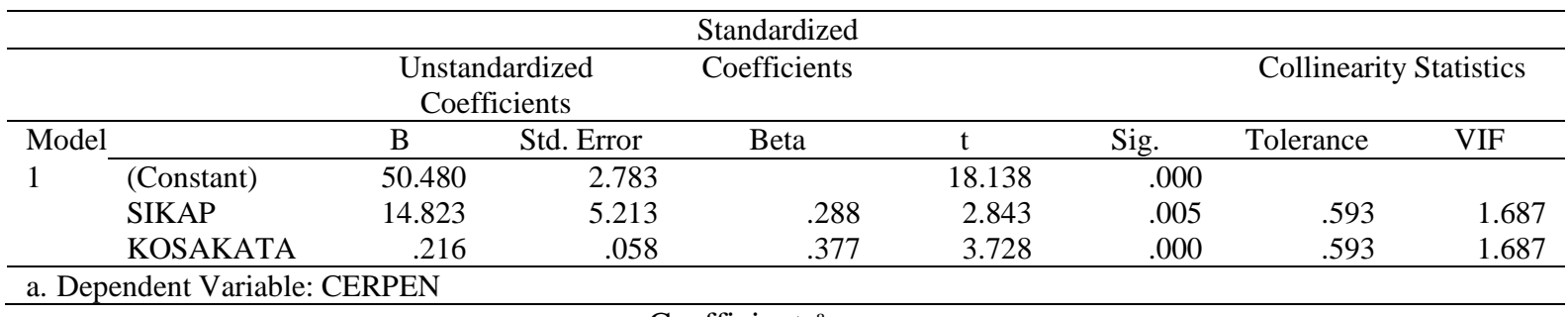

Coefficients $^{\mathrm{a}}$

This multicollinearity test aims to see whether there is a relationship between independent variables. Good data should not correlate to the independent variables. The test criteria are that if the tolerance value of the test result is more than 0.10 , or the VIF (Variance Inflation Factor) value is less than 10, there is no multicollinearity to the tested data. Based on figure 3 , it is seen that the tolerance value of attitude and mastery of vocabulary is 0.593 , while the VIF value between them is 1.687 . This value indicates that between attitude and mastery of vocabulary does not occur multicollinearity.

The next test used is heteroskedasticity 
test. This test is performed to see the symptoms of heteroskedasticity. Good data should not have those symptoms. The occurrence of these symptoms will result in the inaccuracy of the regression model. The results of heteroskedasticity test can see in the following figure.

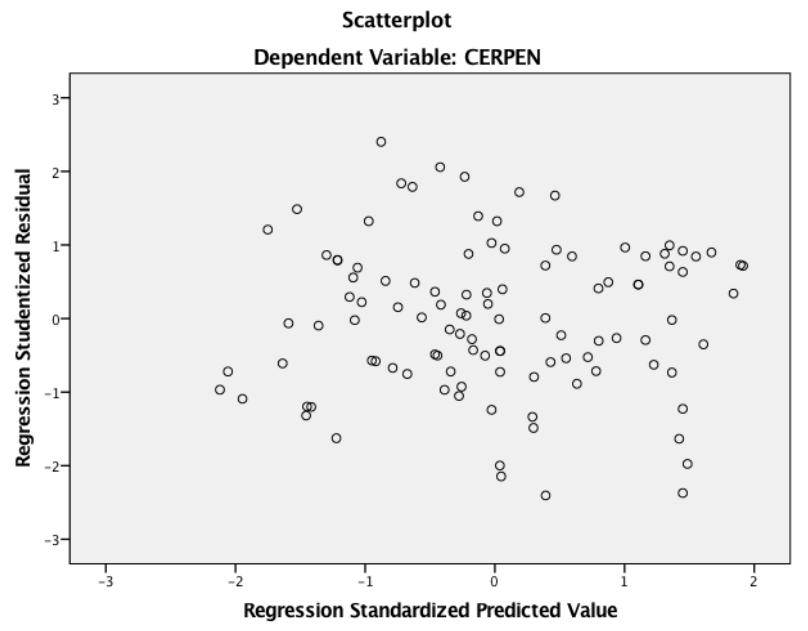

Figure 1 Scatterplot Heteroskedasticity

Based on Figure 1, it can be seen that: (1) The data points of the spreaders are above and below or around zeros, (2) The dots do not collect above or below only, (3) Distribution of data points does not form wavy patterns widen, narrow and then widen again, (4) Distribution of data points is not patterned.

The condition mentioned above shows no symptoms of heteroskedasticity, so there will be no problem with the regression test will be done. Because it meets all four regression assumptions tested above, it can be done multiple linear regression testing to see whether there is a significant contribution simultaneously from learning attitudes and vocabulary mastery to

\section{RESULT AND DISCUSSION}

There are three hypothesis test conducted in this research, and multiple linear regression test is done to see the contribution of learning students' short story writing skills. The hypothesis formulated is as follows.

$\mathrm{H}_{0}$ :There is no significant contribution of learning attitudes and vocabulary mastery simultaneously to students' short story writing skills.

$\mathrm{H}_{\mathrm{a}}$ :There is a significant contribution to learning attitudes and vocabulary mastery simultaneously to students' short story writing skills.

With multiple linear regression test criteria is, $\mathrm{H}_{0}$ is accepted if significance value $>0,05$ and $\mathrm{H}_{0}$ was rejected if value significance $<0,05$. The results obtained are as follows.

attitudes and mastery of vocabulary together to the skills of writing short stories. The results can be seen in the following table 3.5

Table 3.5 Multiple linear regression test results

Model Summary ${ }^{\mathrm{b}}$

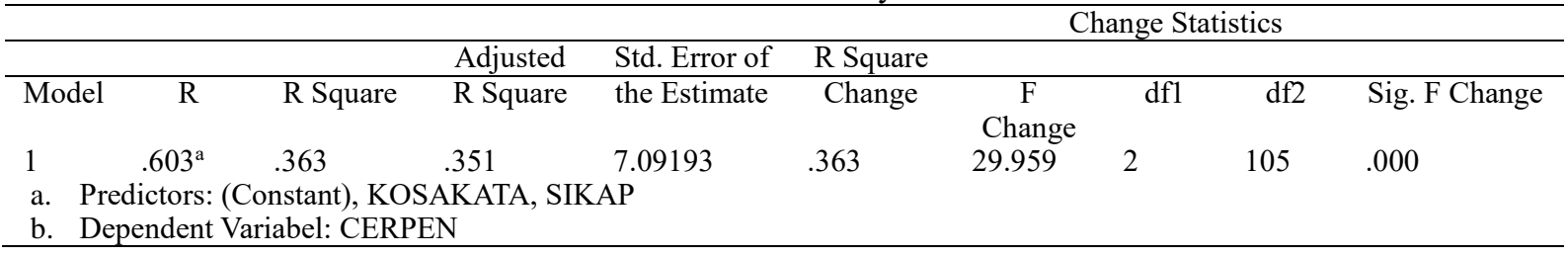

Based on table 3.5 of multiple linear regression test results above, it is seen that the significance of learning attitudes and vocabulary mastery simultaneously is 0.000 . The value is less than the level of significance 0.05 , so the conclusion obtained is rejected $\mathrm{HO}$ and accept $\mathrm{Ha}$ 
that is a significant contribution of learning attitudes and mastery of vocabulary simultaneously to the skills of writing short stories of students. When viewed from the amount of contribution provided by the independent variable, the value of $\mathrm{R}$ Square obtained is 0.363 . It means that the contribution of learning attitudes and vocabulary mastery simultaneously to the skills of writing short stories is equal to $36.3 \%$ and $63.7 \%$ other influenced by other variables not examined in this study.
Furthermore, the contribution of each independent variable to the dependent variable partially can be seen from the value of the significance of each independent variable. The hypothesis of the contribution of learning attitudes to short story writing skills is as follows. $\mathrm{H}_{0} \quad$ : There is no significant contribution of learning attitudes towards students' short story writing skills.

$\mathrm{H}_{\mathrm{a}} \quad$ : There is a significant contribution of learning attitudes towards students' short story writing skills.

Tabel 3.5 The regression coefficient partially

\begin{tabular}{|c|c|c|c|c|c|c|}
\hline & & & & Standardized & & \\
\hline & & \multicolumn{2}{|c|}{ Unstandardized Coefficients } & \multicolumn{2}{|l|}{ Coefficients } & \multirow[b]{2}{*}{ Sig. } \\
\hline Model & & $\mathrm{B}$ & Std. Error & Beta & $\mathrm{t}$ & \\
\hline 1 & (Constant) & 50.480 & 2.783 & & 18.138 & .000 \\
\hline & SIKAP & 14.823 & 5.213 & 288 & 2.843 & .005 \\
\hline & KOSAKATA & .216 & .058 & .377 & 3.728 & .000 \\
\hline
\end{tabular}

Based on the above table, the significance of learning attitudes is 0.005 . The value is less than 0.05 , so the conclusion obtained is that there is a significant contribution of learning attitudes toward the skills of writing short stories of students. Meanwhile, to see the contribution of vocabulary mastery to the skills of short story writing, the hypothesis formulated is as follows.

$\mathrm{H}_{0}$ : There is no significant contribution to vocabulary mastery of students' short story writing skills.

$\mathrm{H}_{\mathrm{a}}$ : There is a significant contribution to vocabulary mastery of students' short story writing skills

The results obtained based on table 3.5 is a significance value of 0.000 . The value is less than 0.05 significance level, so the conclusion obtained is There is a significant contribution of vocabulary mastery of students' short story writing skills.

Furthermore, when viewed from the partial contribution, the value of $\mathrm{R}$ square attitudes of learning to the skills of writing short stories is 0.279 which means the amount of the contribution of learning attitudes toward writing skills short story is $27.9 \%$. For the result of $\mathrm{R}$ Square vocabulary mastery on the skills of writing short stories obtained 0.314 , meaning that the amount of vocabulary mastery contribution to the skills of writing short stories is $31.4 \%$. From table 3.5 can also be prepared regression equation. The equation shows that if the attitude of learning and mastery of vocabulary constant or worth 0 then the skill of writing short stories of students is 50,480 . Regression coefficient equal to 14,823 indicates that the skill of writing the short story of the student will rise 14,823 if the learning attitude has increased as much as 1 unit. Similarly, the regression coefficient is worth 0.216 . It means the skill of writing short stories will rise 0.216 if the student mastery of vocabulary increased by 1 unit. Based on the value of the coefficient is smaller than can be understood that the more dominant independent variables affect student achievement is the mastery of vocabulary.

Based on the results of the above research, it appears that the contribution provided by each variable, as well as collectively are in the medium category. The contribution given indicates that both learning attitudes, as well as vocabulary mastery are important things that must be had to have good short story writing skills. The results also showed that the better the students 'learning attitudes, the better the writing skills of the short story, as well as the wider the mastery of vocabulary students also make the better the students' short story writing skills. Learning attitudes are the students' way of looking at learning. When a student realizes the need to learn, appreciates the learning process, then the learning outcomes will be good too. From the results of the study, students who have good learning attitudes, writing skills short story also be good. Seen from the contribution of learning attitudes of $27.9 \%$ of short story writing skills. This reinforces the results of Ahmadi 
research (2017) and Zulhafizh (2013). Things that also need to have to be skilled in writing short stories is the mastery of vocabulary. Vocabulary becomes a sweetener and also beautify the repertoire of the created story. The more vocabulary you have, the more your story will become. This is also demonstrated by the results of research showing $31.4 \%$ of the vocabulary mastery contribution to short story writing skills. This also reinforces the research results Febrisma (2013) which state that the vocabulary has a very important role in language teaching, the more vocabulary that is owned, the more skilled also someone in the language of writing. Also, Febrina's research results (2014) state that there is a positive relationship between vocabulary mastery and short story writing skills. This research is a development of previous research conducted by Febrina, which in his research does not involve learning attitudes. Based on the results of this study, it is a necessary development of learning that support student to have enough vocabulary, so that it can write a short story better. Learning should also lead students to appreciate and realize the importance of learning.

\section{CONCLUSION AND SUGGESTION}

Based on the results of the research, the conclusion obtained is the attitude of learning and mastery of vocabulary students simultaneously contributed significantly to the skills of writing short stories of students, with a large contribution given is $36.3 \%$; the attitude of learning and mastery of vocabulary in partial also contributed significantly to the skills of writing short stories of students. The major contribution of learning attitudes and vocabulary mastery to the skills of short story writing is $27.9 \%$ and $31.4 \%$, respectively. The suggestions that the author gives to some related parties are: (1) students are expected to improve learning attitudes and vocabulary mastery of short story writing lessons, (2) Indonesian teachers should work with counseling teachers to observe student learning attitudes in the learning process, and (3) for researchers interested in short story writing skills, other factors may be contributing to the variables.

\section{REFERENCE}

Ahmadi, Abu. (2007). Psikologi Sosial. Jakarta: Rineka Cipta.

Febrina, Liga, dkk. (2013). "Kontribusi Minat Baca Cerpen dan Penguasaan Kosakata terhadap Keterampilan Menulis Cerpen Siswa Kelas X MAN 1 Padang". Jurnal Bahasa, Sastra, dan Pengajaran, Vol.1, No. 1, hlm. 80-93.

Febrisma, Nurliya. (2013). "Upaya Meningkatkan Kosakata Melalui Metode Bermain Peran Anak Tunagrahita Ringan (PTK Kelas DV di SLB Kartini Batam)". Jurnal Ilmiah Pendidikan Khusus, Vol. 1, No. 2, hlm. 109-121.

Hakim, Nursal. (2007). Keterampilan Dasar Menulis. Pekanbaru: Cendikia Insani.

Juriah. (2015). "Implementing Controlled Composition to improve Vocabulary Mastery of EFL Students". Dinamika Ilmu, Vol.15, No 1.

Musgrove, Laurence E. (1998). "Attitudes Toward Writing". The Journal of the Assembly for Expanded Perspectives on Learning, Vol. 4, ISS. 1, Article 3.

Paker, T., \&Erarslan, A. (2015). Attitudes of the Preparatory class students the writing course and their attitude-success relationship in writing. Journal of Language and Linguistic Studies, 11 (2), $1-11$.

Petrict, Bojana. (2002). "Students Attitudes towards Writing and Development of Academic Writing Skills". Writing Center Journal, Vol. 22, No.2, p9-27.

Riyanti, Maya, dkk. (2013). "Hubungan Penguasaan Kosakata dengan Kemampuan Menulis Karangan Argumentasi Siswa Kelas XI IPS SMAN 1 GUGUAK 50 KOTA.Vol.1, No 2.

Zulhafizh, dkk. (2013). "Kontribusi Sikap Dan Motivasi Belajar Siswa Terhadap Hasil Belajar Bahasa Indonesia". Jurnal Bahasa, sastra, dan pembelajaran, Vol.1, No 2. Juni. 